\title{
Feeding habits of milk shark, Rhizoprionodon acutus (Ruppell, 1837) in the Gujarat coastal waters of north-eastern Arabian Sea
}

\author{
Swatipriyanka Sen ${ }^{\text {a,* }}$, S.K. Chakraborty ${ }^{\text {b }}$, E. Vivekanandan ${ }^{\text {c }}$, P.U. Zacharia ${ }^{\text {d }}$, A.K. Jaiswar ${ }^{\text {b }}$, \\ Gyanaranjan Dash ${ }^{\text {a }}$, Sangita A. Bharadiya ${ }^{\text {a }}$, Jayshree K. Gohel ${ }^{\text {a }}$ \\ a Veraval Regional Centre of Central Marine Fisheries Research Institute, Veraval-362 269, India \\ ${ }^{\mathrm{b}}$ Central Institute of Fisheries Education, Versova, Mumbai-400 061, India \\ ${ }^{c}$ Madras Research Centre of Central Marine Fisheries Research Institute, Chennai-600 028, India \\ d Central Marine Fisheries Research Institute, Cochin-682 018, India
}

\section{A R T I C L E I N F O}

\section{Article history:}

Received 15 November 2016

Received in revised form 15 October 2017

Accepted 12 November 2017

Available online 26 November 2017

\section{Keywords:}

Diet shift

Ontogenetic changes

Prey preference

Feeding behaviour

\begin{abstract}
A B S T R A C T
The feeding habit of milk shark Rhizoprionodon acutus was investigated in 684 specimens collected along Gujarat coast (India) of north-eastern Arabian Sea from January 2013 to December 2014. The length range of females was $32-89.6 \mathrm{~cm}$ and males $33.5-89 \mathrm{~cm}$. The shark foraged on diversified prey items which were pooled into four distinct groups i.e., teleosts, crustaceans, mollusks and annelids. Teleosts (Dietary coefficient, \%QI $=83.05$ and index of relative importance, \%IRI $=78.40$ ) were found to be the preferred food items followed by crustaceans $(\% Q I=16.21$; \% $R I=19.78)$, which formed the secondary food item group. Mollusks $(\% Q I=0.74 ; \% I R I=1.69)$ and annelids $(\% Q I=0.01 ; \% I R I=0.14)$ constituted the accidental or accessory food items. The species, though is a pelagic predator, probably performs vertical movements in search of prey items. The shark also showed some sorts of preference and selectivity for clupeids, engraulids and carangids. Females though showed significantly lower index of relative fullness (IRF) $(P \leq 0.5)$ and comparatively lower vacuity index and lower mean number of preys per stomach compared to the males, the preference for prey items was not found to be significantly different between the females and males. Juveniles were found to have significantly higher IRF $(P \leq 0.5)$ and comparatively higher vacuity index than that of the adults, whereas the mean preys per stomach was found to be lower than that of the adults. Moreover, the prey preference was also significantly different between the juveniles and adults. The study provides necessary baseline information about the feeding habits of the shark in the region which will be helpful in understanding the trophodynamics of the species under the influence of overfishing and climate change.
\end{abstract}

(C) 2017 Elsevier B.V. All rights reserved.

\section{Introduction}

Sharks, due to high demand for their meat, fins, liver and other products, are exclusively targeted by the fishing industry around the world as a result of which many of them are now at a verge of population collapse. Sharks also form an important group among the marine fishery resources exploited in India, where about $68 \%$ of the sharks landed in India are from Arabian Sea along the west coast (Kizhakudan et al., 2015). Apart from their fishery importance, sharks also play a crucial role in the marine ecosystem as apex predators in balancing the ecology and structure of regional marine communities (Cortes, 1999; Gelsleichter et al., 1999; Stevens et al., 2000). Moreover, sharks being at the top of the food chain are usually found in lower biomass compared to

\footnotetext{
* Correspondence to: Demersal Fisheries Division, Veraval Regional Centre of Central Marine Fisheries Research Institute, Veraval-362 269, India.

E-mail address: swathipriyanka.sen@icar.gov.in (S. Sen).
}

other fishes occupying lower trophic levels (Bonfil, 1994; Camhi et al., 1998). Therefore, targeted over-exploitation of predators like sharks might result in their population collapse leading to trophic cascade in subsequent lower trophic levels and serious ecological consequence that can adversely affect the overall fishery (Heithaus et al., 2008). Therefore, information on diet composition of sharks is essential to assess their interdependence and influence on other trophic levels in the ecosystem.

Gujarat, the largest maritime state in India, with its gulfs and broadest continental shelf is bestowed with one of the richest marine biodiversities and ecosystems of the north-eastern Arabian Sea. Presently, Gujarat is the highest marine fish producing state (about 0.7 million tonnes per annum) in India subcontinent and is also considered as an important centre for the fisheries activities along the north-eastern Arabian Sea.

A large fishery for sharks once existed along Gujarat coast, which contributed more than half of India's total shark landings (Vivekanandan, 2001). However, the shark landing has declined 
since 2000 and is experiencing severe fluctuations due to unsustainable exploitation. Rhizoprionodon acutus, also popularly known as 'milk shark', was one of the important shark species landed along Gujarat coast of north-eastern Arabian Sea but is now showing drastic decline in catch for the last few decades. To understand the reason behind this decrease in catch of the species and its possible impact on other trophic levels and ecosystem, it is essential to study its feeding ecology. $R$. acutus, though an inshore pelagic shark, is found up to a depth of $200 \mathrm{~m}$ and is widely distributed in tropical and sub-tropical estuarine and coastal waters (Compagno, 1984; Simpfendorfer, 2003). Despite its wide distribution, there is a paucity of information on the feeding ecology of this species except for few previous publications from Senegalese waters (Cadenat and Blache, 1981; Capape et al., 1994; Ba et al., 2013) and from Persian Gulf (Jabado et al., 2015). As the dietary composition of different species of sharks varies depending upon the geographical locations (Lowe et al., 1996; Simpfendorfer et al., 2001), it is essential to study the feeding habit of $R$. acutus from different regions of world oceans, so as to provide necessary baseline information to understand the ecological significance of the species. Therefore, the present study was envisaged to understand the dietary composition, breadth and any possible changes due to maturity stage and sex of $R$. acutus along Gujarat coast of India.

\section{Material and methods}

\subsection{Sampling}

A total of $684 R$. acutus specimens were obtained for the study during January, 2013 to December 2014 from 4 major fish landing centres i.e., Veraval $\left(20.905^{\circ} \mathrm{N}\right.$; $\left.70.375^{\circ} \mathrm{E}\right)$, Mangrol $\left(21.107{ }^{\circ} \mathrm{N}\right.$; $\left.70.100{ }^{\circ} \mathrm{E}\right)$, Porbandar $\left(21.640^{\circ} \mathrm{N} ; 69.596^{\circ} \mathrm{E}\right)$ and Okha $(22.444$ ${ }^{\circ} \mathrm{N} ; 69.056^{\circ} \mathrm{E}$ ) along Gujarat coast (India) of north-eastern Arabian Sea (Fig. 1). The collected specimens were immediately preserved by placing in insulated ice box and transported to the laboratory of Veraval Regional Centre of Central Marine Fisheries Research Institute (CMFRI, Gujarat, India) for analysis. Data on total body length (TL) i.e., from tip of snout to posterior tip of tail, with tail flexed down to midline of each individual was measured to the nearest $1.0 \mathrm{~cm}$ using a soft tape along the side of the body following the method described by Compagno (1984). The individual body weight was also measured to the nearest g using an electronic weighing balance (Sunrise SVT, India). The male sharks were categorized into juveniles or adults depending on the level of calcification of clasper and development of testes. Similarly, female sharks were categorized into juveniles or adults depending on the level of development of ovary, oviducal gland and oocytes. Maturity data of the sharks were analysed and individual sharks measuring TL $60 \mathrm{~cm}$ or above were considered as adults and below $60 \mathrm{~cm}$ as juveniles (Sen et al., 2017).

Gut was removed from each individual and dissected to remove the content. The gut content was washed gently to remove mucus and other secretory substances and was blotted dry using tissue paper. The food items were identified and classified to the lowest possible taxonomic levels using various identification guides (Fischer et al., 1981; Seret and Opic, 1981; Bellemans et al., 1988). Prey items were identified from external morphology or whenever necessary with the use of a stereo-zoom microscope (Leica S8 APO, Germany) depending on the digestion stage of each item. For comparisons, prey items were grouped into the following major taxonomic groups viz., Teleosts, Crustaceans, Mollusks and Annelids (Cortes, 1997). The prey items under each taxonomic group were meticulously counted and weighed to the nearest mg. The food items which were beyond recognition due to excessive digestion were classified as unidentified items for the group of prey (ex. unidentified fishes and unidentified crustaceans).

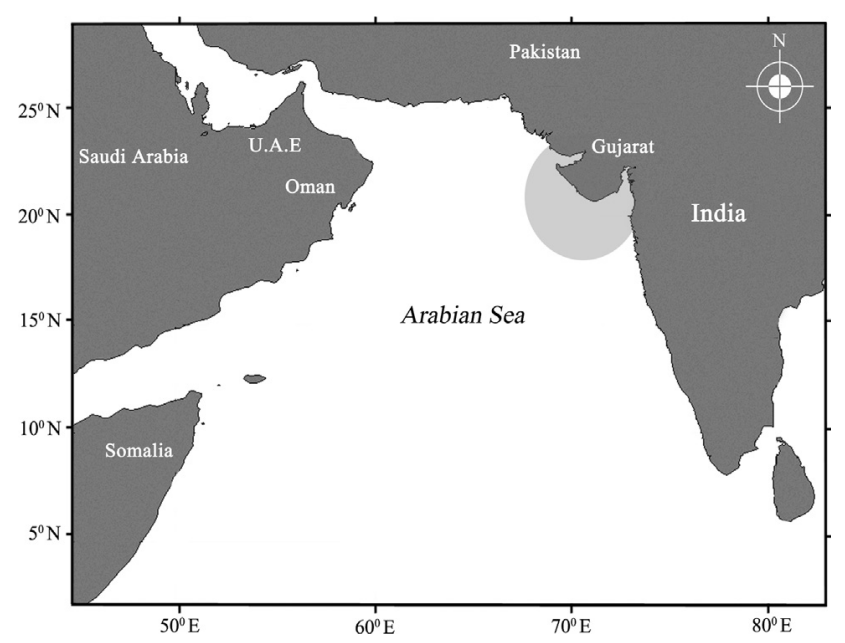

Fig. 1. Map showing the sampling area along Gujarat coast of India from which the specimens for the present study were collected.

\subsection{Analysis of diet composition}

The importance of each prey item in the diet of $R$. acutus was assessed by two conventional indices viz., (1) index of relative importance (IRI) following the method described by Hyslop (1980) and (2) dietary coefficient (QI) following the method described by Salgado et al. (2004). Three sub-indices, viz. (1) the numerical index (NI) i.e., the percentage of each prey item in relation to the total number of prey items; (2) the occurrence index (OI) i.e., the percentage of stomachs containing a prey type in relation to the total number of all non-empty stomachs and (3) the gravimetric index (GI) i.e., the percentage of each prey item weight in relation to the total wet weight of all food items were used for obtaining the values of the above mentioned two conventional indices.

The first index, i.e., IRI of each prey item was calculated by using following formula.

$I R I=(N I+G I) \times O I$

The IRI values thus obtained for each prey item were converted to a percentage (\% IRI) for the ease of comparison using the following formulae (Cortes, 1997).

$\% I_{i} I_{i}=100 \operatorname{IRI}_{i} \sum_{I=i}^{n} I R I$

The \%IRI values were used to classify the prey items using the method described by Rosecchi and Nouaze (1987). The prey items constituting $50 \%$ of the total sum are considered preferential food items, next $25 \%$ as secondary food items and the remaining $25 \%$ as accessory food items.

Similarly, the second index, i.e., QI of each prey item was calculated using the following formula

$Q I=N I \times G I$

Based on the QI score, the prey items were classified as dominant $(Q I \geq 200)$, secondary $(200>Q I \geq 20)$ or accidental $(Q I<20)$ categories.

\subsection{Diet breadth}

The diet breadth of the species, determined to the lowest taxonomical level possible for each prey item, was compared with following three indices: 


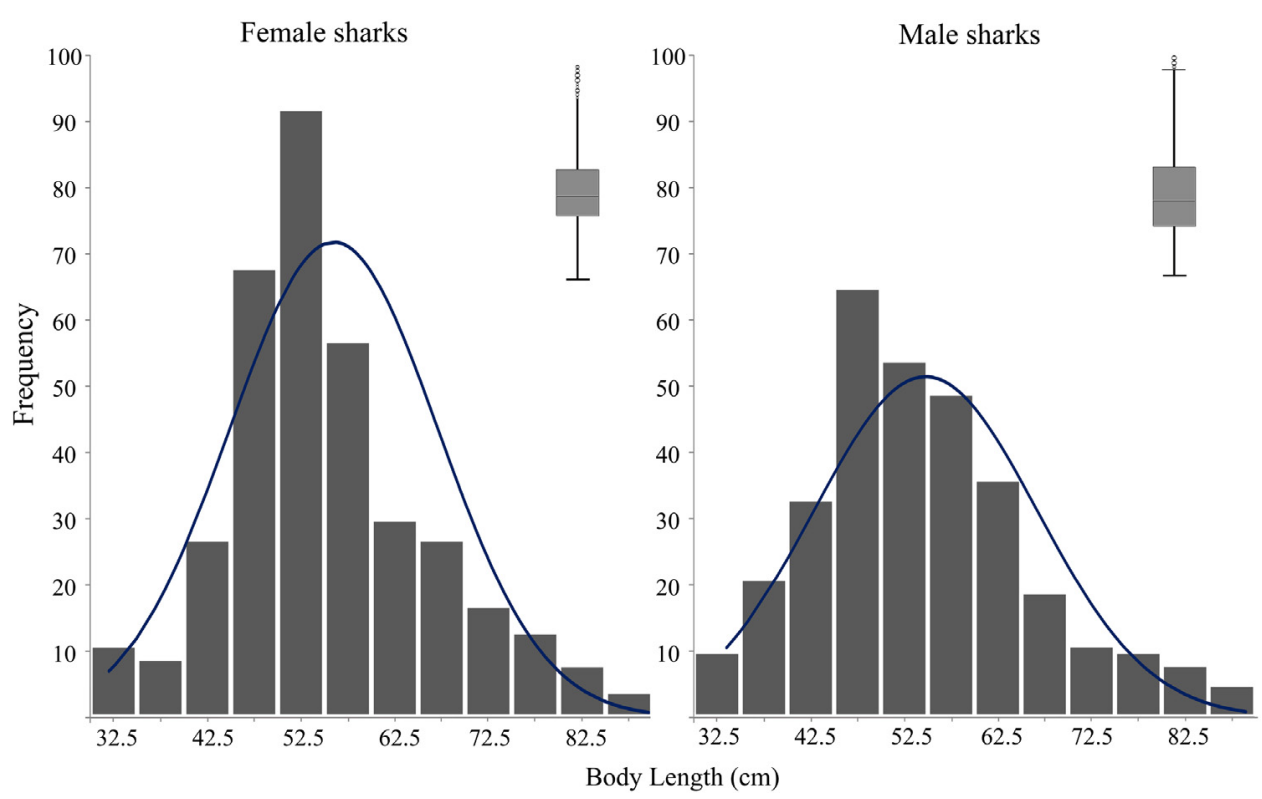

Fig. 2. Length frequency histogram and box plot of sampled Rhizoprionodon acutus female and male specimens collected along Gujarat coast of India.

(a) The Shannon-Wiener index $\left(H^{\prime}\right)$, which indicates species frequency distribution, i.e., how individuals are distributed amongst the species, was calculated using the following formulae.

$H^{\prime}=-\sum_{i=1}^{S}\left(P_{i} \log P_{i}\right)$

Where, $S=$ the total number of species; and $P_{\mathrm{i}}$ is the frequency of the $i^{\text {th }}$ species. The index provides idea about the richness as well as the evenness of the community.

(b) The Pielou's index $\left(J^{\prime}\right)$, which indicates the evenness i.e., how evenly the different species composing the diet of shark are distributed, is calculated using the following formulae

$J^{\prime}=\frac{H^{\prime}}{\log S}$.

Where, $H$ ' is the Shannon-Wiener index and ' $S$ ' is the number of species recorded in the diet. The value of $J^{\prime}$ varies between 0 to 1 and depends on the variation in communities among the species.

(c) Margalef's index (d), which indicates species richness i.e., how richly the diet of the shark is composed of different prey taxa, was calculated using following formulae.

$d=\frac{S-1}{\log N}$

Where, ' $N$ ' is the total number of individuals present in the diet and ' $S$ ' is the number of species recorded in the diet.

\subsection{Diet shift}

The difference in feeding behaviour such as intensity of feeding and foraging strategies between sexes and due to ontogenetic shift were assessed using following indices. Intensity of feeding activity was evaluated by the vacuity index (VI), which was calculated as the percentage of empty stomachs (number of stomachs without prey/total number of stomachs) $\times 100$ (Hyslop, 1980). The index of Relative Fullness (IRF) was derived by dividing the total weight ( $\mathrm{g}$ ) of the gut content for a given shark by the total weight $(\mathrm{g})$ of that shark (Barry et al., 2008). The data on IRF for different groups were tested using Kolmogorov-Smirnov test and found to be deviating from normal distribution. Therefore, differences in diet quantity between life stages and sexes were assessed with Mann-Whitney's test for two groups and Kruskal-Wallis test for more than two groups. The mean number of preys per stomach was calculated for each sex and maturity stage separately.

To find out any possible differences in dietary preferences between the sexes and from ontogenetic shift, diet compositions were examined separately for juveniles and adults as well as for males and females. The individual prey abundance data collected from the diets of males, females, juveniles and adults separately were used for the analysis using PRIMER 6 (Ver.6.1.13, PRIMER-E Ltd.). The data were first standardized (by sample total) and then transformed (square root). Consequent to these pretreatments, the data were tested for resemblance between the males, females, juveniles and adults using Bray-Curtis similarity test. The analysis of similarity test (ANOSIM) was performed through ANOVA to find out the difference between the sexes and between the juveniles and adults. CLUSTER analysis was carried out with SIMPROF test to group samples through dendrogram plot using their resemblance in terms of prey preference. A non-metric multi-dimensional scaling (MDS) analysis was carried out with overlaid cluster from dendrogram plot to depict the similarities and dissimilarities among males, females, juveniles and adults.

\section{Results}

\subsection{Sample structure}

A total of 684 sharks were processed for the study of which female constituted 53\% $(n=363)$ and male $47 \%(n=321)$ with an overall sex ratio (Male: Female) of $1: 1.13$. The mean TL of female sharks $(55.98 \pm 0.58 \mathrm{~cm})$, was not found to be significantly higher than that of the males i.e., $54.77 \pm 0.67 \mathrm{~cm}$ (Independent t-test, $P$ $>0.01$ ). The length of female sharks was found to be in a TL range between $32 \mathrm{~cm}$ to $89.6 \mathrm{~cm}$ and was mainly dominated by individuals in the length group of 50-55 cm (Fig. 2). The length ranges of male sharks was between $33.5 \mathrm{~cm}$ and $89 \mathrm{~cm}$ but were dominated by comparatively smaller length group of $45-50 \mathrm{~cm}$ (Fig. 2).

\subsection{Diet composition}

Teleosts (\%QI $=83.05$; \%IRI $=78.40$ ) were found to be the dominant as well as preferential food items of the shark followed 
Table 1

Classification of prey groups of Rhizoprionodon acutus from Gujarat waters of India according to the dietary coefficient (QI) and the index of relative importance (IRI).

\begin{tabular}{llllrll}
\hline Prey groups & \multicolumn{1}{l}{ QI } & QI\% & Prey type & \multicolumn{1}{l}{ IRI } & \multicolumn{1}{l}{ IRI\% } & Prey type $^{* *}$ \\
\hline Teleost & 742.69 & 83.05 & Dominant & 2018.92 & 78.40 & Preferential \\
Crustacean & 144.95 & 16.21 & Secondary & 509.32 & 19.78 & Accessory \\
Mollusks & 6.64 & 0.74 & Accidental & 43.52 & 1.69 & Accessory \\
Annelids & 0.03 & 0.00 & Accidental & 3.54 & 0.14 & Accessory \\
\hline
\end{tabular}

" For the QI, prey groups are classified as dominant if $\mathrm{QI} \geq 200$, secondary if $200>\mathrm{QI} \geq 20$, or accidental if $\mathrm{QI}<20$.

*** For the IRI, prey groups are classified as dominant if contribution of group is $50 \%$ of IRI. The next $25 \%$ contributors are secondary, and the remaining $25 \%$ are considered as accessory prey group.

by Crustaceans $(\% \mathrm{QI}=16.21$; \% IRI $=19.78)$, which formed the secondary accessory food item group. Mollusks $(\% Q I=0.74$; $\% I R I=1.69)$ and Annelids $(\% Q I=0.01 ; \% I R I=0.14)$ constituted the accidental accessory food items whose contributions were very negligible (Table 1 ). The teleosts in the diet of sharks were mainly contributed by clupeids, anchovies, sciaenids, cardinal fishes, threadfin breams etc. (Table 2). However, a major portion (nearly about $62 \%$ ) of the teleosts in gut could not be accurately identified due to advance stage of digestion. Crustaceans, the secondary accessory food items were constituted by penaeid and nonpenaeid shrimps, crabs and stomatopods (Table 2). In the case of shrimps also a major fraction (nearly about $18 \%$ ) of the samples was unidentifiable due to advance stage of digestion. Mollusks, the accidental accessory food items were mainly constituted by cephalopods like squids and cuttlefishes (Table 2). The gastropods and annelids recovered from the stomach were disintegrated beyond the level of identification. Nevertheless, a total of 25 genera of teleosts representing 19 families, 7 genera of crustaceans representing 5 families and 3 genera of mollusks representing 3 families were identified to have constituted the diet of the shark.

\subsection{Diet breadth}

The overall Shannon-Wiener index $\left(H^{\prime}\right)$, Pielou's index of evenness $\left(J^{\prime}\right)$ and Margalef's index of richness (d) for the diet of different sexes and maturity stages of $R$. acutus are given in Table 3. No much variation in the biodiversity indices was observed for the prey items of the male and female sharks. However, the biodiversity indices for prey items of adult sharks were found to be higher than that of the juvenile sharks. With highest variety of prey items, the dietary breadth of adult female sharks showed highest Margalef's index of richness and highest Pielou's index of evenness for the prey species. Thus the Shannon-Wiener index of biodiversity was also highest for the gut content of the adult female sharks. The biodiversity indices decreased gradually for the gut content of the adult male sharks and adult female sharks showing the lowest richness and evenness of prey items for the juvenile female sharks.

\subsection{Diet shift}

In the present study, out of 684 shark specimens analysed, 355 sharks had food contents in their gut and remaining sharks had empty guts, which resulted an overall vacuity index of $48.10 \%$ (Table 4). The vacuity index for females was lower than the males. The adults showed lower vacuity index compared to the juveniles. In the case of females the adults showed lower vacuity index compared to the juveniles. Similarly, in the case of males, the adults showed lower vacuity index compared to the juveniles.

The index of relative fullness (IRF) of females was significantly lower than the males (Mann-Whitney U test, $P<0.05$ ). An ontogenetic shift in feeding behaviour was apparent as the juveniles showed a significantly higher IRF compared to the adults (MannWhitney U test, $P<0.05$ ) (Table 4). The adult females were found to have significantly lowest (Kruskal-Wallis test, $P<0.05$ ) IRF compared to the juveniles of both the sexes as well as the adults of males. On the other hand, the juveniles of female sharks showed highest IRF (Kruskal-Wallis test, $P<0.05$ ) compared to the adults of both the sexes as well as the juveniles of males. Mean number of preys per stomach of females was found to be lower than the males (Table 4). Similarly, the mean number of preys per stomach of juveniles was found to be lower than the adults.

Visible differences in prey preference was also noticed as the relative importance of different prey groups were found to be different among the juvenile females, adult females, juvenile males and adult males (Figs. 3 and 4). However, the prey preference was not significantly different between the males and females (ANOSIM global $\mathrm{R}=0 ; P>0.05$ ). Contrary to this, the prey preference was significantly different between the juveniles and adults (ANOSIM global $R=1 ; P<0.05$ ). The findings of the CLUSTER analysis as resemblance dendrogram plot and MDS analysis were shown in Figs. 5 and 6, respectively. The cluster analysis with SIMPROF test showed a resemblance of $80.83 \%$ indicating a non significant difference in prey preference between the adult males and adult females (SIMPROF, $P>0.05$ ). Similarly, nonsignificant difference in prey preference was observed between the juvenile males and juvenile females which showed a resemblance of 79.23\% (SIMPROF, $P>0.05$ ). However, the prey preferences between the juveniles and adults of both the male and females were significantly different with a lower resemblance of $71.44 \%$ (SIMPROF, $P<0.05$ ). The MDS analysis showed clear separate clusterings for the juveniles and adults of both the sexes at $75 \%$ similarity which disappeared when tested for $70 \%$ similarity clearly indicating absence of any significant difference with respect to prey preference between the males and females.

\section{Discussion}

There are several earlier studies where the feeding habit of $R$. acutus has thoroughly been investigated from other regions. Nonetheless, there were no prior studies where attempts have been made to understand the feeding habits of the species from the north-eastern Arabian Sea. The findings of the present study, for the first time, demonstrate the dietary composition, feeding behaviour, prey preference and dietary shifts of $R$. acutus from the region. In the present study, specimens were collected along the Gujarat coast (India) of Arabian Sea owing to its fisheries significance as well as biodiversity and ecological importance in the region. The number of females though found to be marginally higher than males, the sex ratio did not differ significantly. The present study evidenced that the teleosts are the preferential as well as dominant food items which contributed about $78.40 \%$ to the diet of the shark followed by crustaceans (19.78\%), mollusks (1.69\%) and annelids (0.14\%). The finding of the present study agrees well with Jabado et al. (2015) who reported that the shark off Persian gulf feeds mainly on a variety of teleosts but also depends on crustaceans and cephalopods to some extent. Several other studies have also confirmed teleosts as the most preferred 


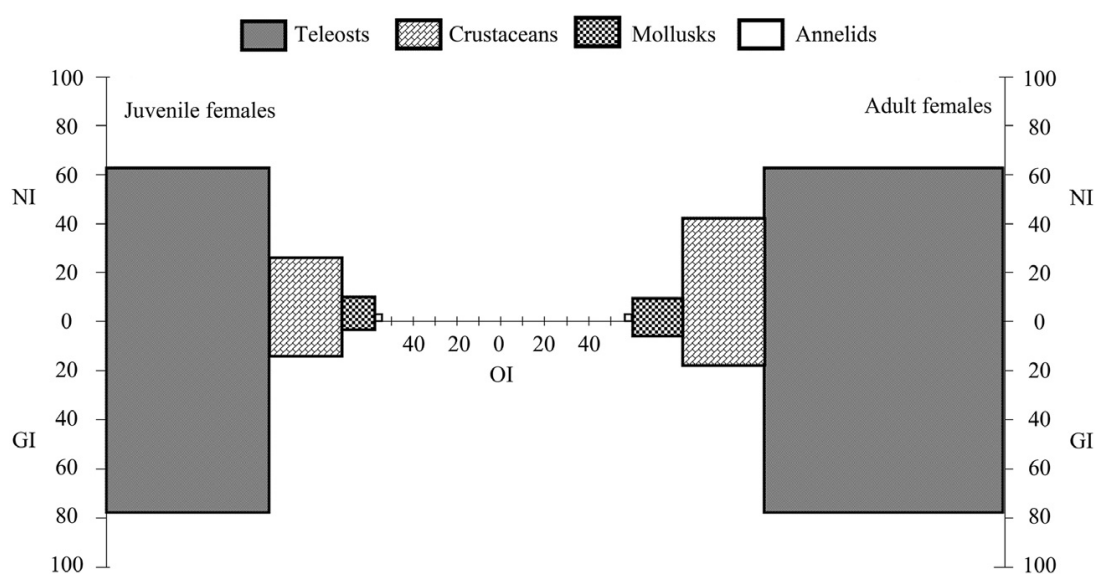

Fig. 3. Graphical presentation of relative importance of each prey category for juvenile females and adult females of Rhizoprionodon acutus illustrated by using the combined values of the percent number (numerical index, $\mathrm{NI}$ ), percent weight (gravimetric index, GI), and frequency of occurrence (occurrence index, $\mathrm{OI}$ ).

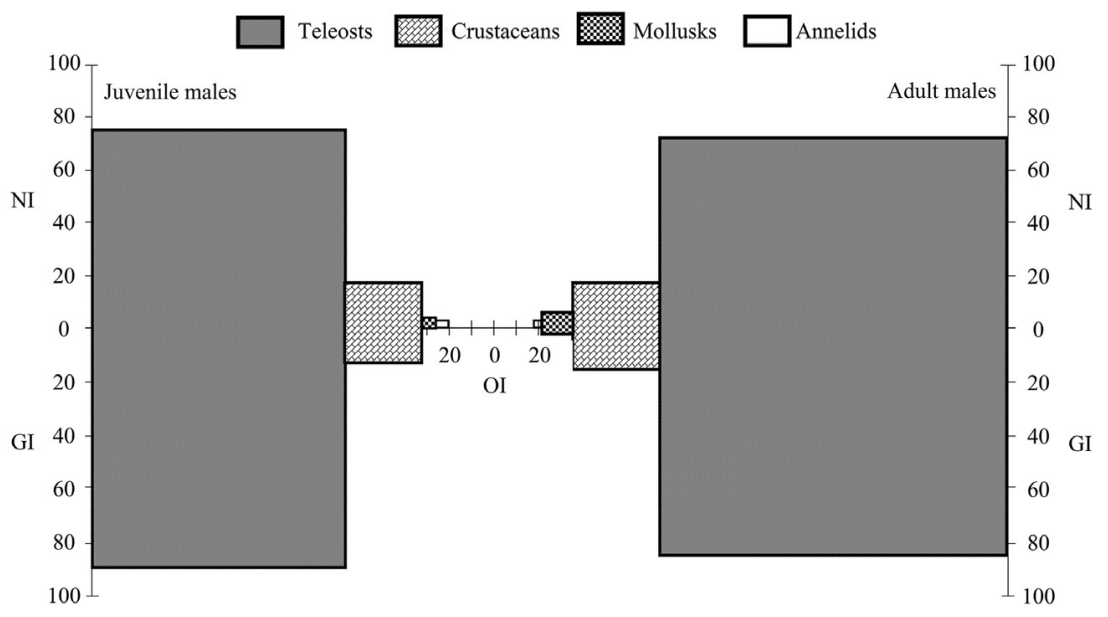

Fig. 4. Graphical presentation of relative importance of each prey group for the juvenile males and adult males of Rhizoprionodon acutus illustrated by using the combined values of the percent number (numerical index, NI), percent weight (gravimetric index, GI), and frequency of occurrence (occurrence index, OI).

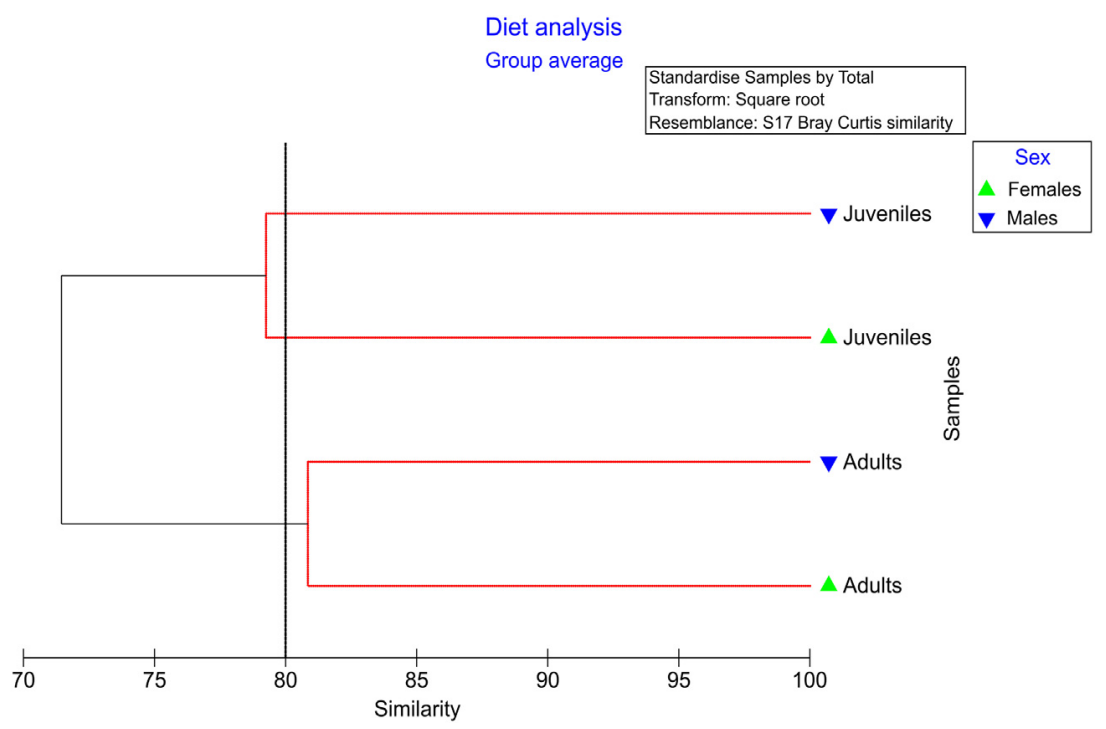

Fig. 5. Dendrogram plot showing the grouping of the juveniles and adults of female and male sharks through CLUSTER analysis with SIMPROF test using their resemblance in terms of prey preference. 
Table 2

Diet composition of Rhizoprionodon acutus from Gujarat waters of India expressed as percentages number (NI), percentage by weight (GI), frequency of occurrence (OI), dietary coefficient (QI) and index of relative importance (IRI) of prey items.

\begin{tabular}{|c|c|c|c|c|c|c|c|}
\hline Food items & $\mathrm{NI}$ & GI & $\mathrm{OI}$ & $\mathrm{QI}$ & QI\% & IRI & IRI\% \\
\hline $\begin{array}{l}\text { Teleosts } \\
\text { Clupeidae (Sardines) }\end{array}$ & 69.01 & 81.85 & 113.52 & 742.69 & 83.05 & 2018.92 & 78.40 \\
\hline Sardinella longiceps & 4.58 & 6.57 & 7.61 & 30.10 & 3.37 & 84.81 & 3.29 \\
\hline $\begin{array}{l}\text { Tenualosa sp. } \\
\text { Engraulidae (Anchovies) }\end{array}$ & 2.44 & 2.11 & 4.51 & 5.15 & 0.58 & 20.51 & 0.80 \\
\hline Thryssa sp. & 3.05 & 2.93 & 5.35 & 8.96 & 1.00 & 32.05 & 1.24 \\
\hline Stoliphorus sp. & 5.19 & 2.93 & 9.57 & 8.19 & 0.91 & 40.73 & 1.58 \\
\hline $\begin{array}{l}\text { Coilia dussumieri } \\
\text { Carangidae (Carangids) }\end{array}$ & 1.22 & 0.93 & 1.69 & 1.13 & 0.13 & 3.63 & 0.14 \\
\hline Caranx ignobilis & 1.68 & 1.38 & 2.82 & 2.32 & 0.26 & 8.62 & 0.33 \\
\hline $\begin{array}{l}\text { Alepes sp. } \\
\text { Scombridae (Mackerels) }\end{array}$ & 1.22 & 0.65 & 2.25 & 0.79 & 0.09 & 4.21 & 0.16 \\
\hline $\begin{array}{l}\text { Rastrelliger kanagurta } \\
\text { Apogonidae (Cardinal fishes) }\end{array}$ & 0.92 & 0.88 & 1.69 & 0.81 & 0.09 & 3.04 & 0.12 \\
\hline $\begin{array}{l}\text { Apogon sp. } \\
\text { Nemipteridae (Threadfin breams) }\end{array}$ & 3.21 & 3.72 & 5.92 & 11.91 & 1.33 & 40.95 & 1.59 \\
\hline $\begin{array}{l}\text { Nemipterus japonicus } \\
\text { Sciaenidae (Croakers) }\end{array}$ & 2.60 & 3.06 & 4.79 & 7.94 & 0.89 & 27.08 & 1.05 \\
\hline Otolithes biaruiatus & 2.44 & 4.51 & 4.23 & 11.02 & 1.23 & 29.37 & 1.14 \\
\hline $\begin{array}{l}\text { Johnius glaucus } \\
\text { Platycephalidae (Flat heads) }\end{array}$ & 3.51 & 3.90 & 5.92 & 13.69 & 1.53 & 43.83 & 1.70 \\
\hline $\begin{array}{l}\text { Platycephalus sp. } \\
\text { Trichiuridae (Ribbon fishes) }\end{array}$ & 1.83 & 2.33 & 3.10 & 4.28 & 0.48 & 12.91 & 0.50 \\
\hline $\begin{array}{l}\text { Trichiurus lepturus } \\
\text { Hemiramphidae (Halfbeaks) }\end{array}$ & 1.98 & 2.27 & 2.25 & 4.50 & 0.50 & 9.58 & 0.37 \\
\hline $\begin{array}{l}\text { Hemiramphus sp. } \\
\text { Muraenesocidae (Pike congers) }\end{array}$ & 0.92 & 0.79 & 1.69 & 0.73 & 0.08 & 2.89 & 0.11 \\
\hline $\begin{array}{l}\text { Congresox talabonoides } \\
\text { Cynoglossidae (Flat fishes) }\end{array}$ & 1.22 & 2.14 & 1.97 & 2.62 & 0.29 & 6.63 & 0.26 \\
\hline $\begin{array}{l}\text { Cynoglossus arel } \\
\text { Synodontidae (Lizard fishes) }\end{array}$ & 1.98 & 1.78 & 3.66 & 3.53 & 0.39 & 13.78 & 0.54 \\
\hline $\begin{array}{l}\text { Harpadon nehereus } \\
\text { Polynemidae (Thread fins) }\end{array}$ & 1.53 & 1.85 & 2.54 & 2.82 & 0.32 & 8.55 & 0.33 \\
\hline Polynemus indicus & 1.07 & 1.34 & 1.97 & 1.43 & 0.16 & 4.74 & 0.18 \\
\hline $\begin{array}{l}\text { Pseudorhombus sp. } \\
\text { Mugilidae (Mullets) }\end{array}$ & 1.22 & 1.05 & 2.25 & 1.29 & 0.14 & 5.13 & 0.20 \\
\hline $\begin{array}{l}\text { Mugil cephalus } \\
\text { Epinephalidae (Groupers) }\end{array}$ & 1.68 & 1.72 & 1.41 & 2.89 & 0.32 & 4.79 & 0.19 \\
\hline $\begin{array}{l}\text { Epinephelus diacanthus } \\
\text { Lethrinidae (Emperor snappers) }\end{array}$ & 0.76 & 0.39 & 1.13 & 0.29 & 0.03 & 1.29 & 0.05 \\
\hline $\begin{array}{l}\text { Lethrinus sp. } \\
\text { Lutjanidae (Snappers) }\end{array}$ & 0.92 & 0.41 & 1.13 & 0.37 & 0.04 & 1.49 & 0.06 \\
\hline $\begin{array}{l}\text { Lutjanus sp. } \\
\text { Leiognathidae (Pony fishes) }\end{array}$ & 1.22 & 0.96 & 2.25 & 1.18 & 0.13 & 4.92 & 0.19 \\
\hline Leiognathus sp. & 0.76 & 0.28 & 0.28 & 0.22 & 0.02 & 0.29 & 0.01 \\
\hline Unidentified fishes & 19.85 & 30.96 & 31.55 & 614.56 & 68.72 & 1603.08 & 62.25 \\
\hline Crustaceans & 21.53 & 15.09 & 36.90 & 144.95 & 16.21 & 509.32 & 19.78 \\
\hline $\begin{array}{l}\text { Squillidae (Stomatopods) } \\
\text { Oratosquilla sp. } \\
\text { Portunidae (Crabs) }\end{array}$ & 1.22 & 0.70 & 2.25 & 0.86 & 0.10 & 4.34 & 0.17 \\
\hline Portunus sanguinolentus & 0.61 & 0.41 & 1.13 & 0.25 & 0.03 & 1.15 & 0.04 \\
\hline $\begin{array}{l}\text { Callinectes sp. } \\
\text { Penaeidae (Penaeid shrimps) }\end{array}$ & 1.98 & 0.42 & 3.66 & 0.83 & 0.09 & 8.80 & 0.34 \\
\hline $\begin{array}{l}\text { Parapenaeopsis stylifera } \\
\text { Solenoceridae(Penaeid shrimps) }\end{array}$ & 2.14 & 0.78 & 3.38 & 1.67 & 0.19 & 9.87 & 0.38 \\
\hline Solenocera crassicornis & 0.76 & 0.35 & 1.41 & 0.27 & 0.03 & 1.57 & 0.06 \\
\hline $\begin{array}{l}\text { Solenocera choprai } \\
\text { Sergestidae (Non-penaeid shrimps) }\end{array}$ & 0.92 & 0.59 & 1.41 & 0.54 & 0.06 & 2.12 & 0.08 \\
\hline Acetes sp. & 1.98 & 0.04 & 3.66 & 0.08 & 0.01 & 7.42 & 0.29 \\
\hline Unidentified shrimps & 11.91 & 11.79 & 20.00 & 140.45 & 15.71 & 474.06 & 18.41 \\
\hline Mollusks & 8.09 & 3.04 & 15.21 & 6.64 & 0.74 & 43.52 & 1.69 \\
\hline $\begin{array}{l}\text { Sepiidae (Cephalopods-Cuttle fishes) } \\
\text { Sepia sp. } \\
\text { Loliginidae (Cephalopods-Loligo) }\end{array}$ & 2.14 & 1.09 & 3.66 & 2.32 & 0.26 & 11.81 & 0.46 \\
\hline $\begin{array}{l}\text { Uroteuthis duvaucelii } \\
\text { Octopodidae(Cephalopods-Octopus) }\end{array}$ & 2.60 & 1.07 & 4.79 & 2.76 & 0.31 & 17.53 & 0.68 \\
\hline $\begin{array}{l}\text { Octopus vulgaris } \\
\text { Gastropoda (Gastropods) }\end{array}$ & 1.83 & 0.61 & 3.10 & 1.12 & 0.13 & 7.57 & 0.29 \\
\hline Unidentified gastropods & 1.53 & 0.28 & 3.66 & 0.43 & 0.05 & 6.61 & 0.26 \\
\hline Annelids & & & & & & & 0.14 \\
\hline $\begin{array}{l}\text { Annelida (worms) } \\
\text { Unidentified worms }\end{array}$ & 1.37 & 0.02 & 2.54 & 0.03 & 0.00 & 3.54 & 0.14 \\
\hline
\end{tabular}


Table 3

Biodiversity indices for the prey items of Rhizoprionodon acutus from Gujarat waters of India.

\begin{tabular}{llllll}
\hline Sex and maturity stages & $S$ & $N$ & $H^{\prime}$ & $J^{\prime}$ & $d$ \\
\hline Female sharks & 39 & 312 & 3.18 & 0.87 & 6.62 \\
Male sharks & 40 & 343 & 3.22 & 0.87 & 6.68 \\
Juvenile sharks & 37 & 256 & 3.03 & 0.84 & 6.49 \\
Adult sharks & 40 & 399 & 3.29 & 0.89 & 6.51 \\
Juvenile female sharks & 30 & 117 & 2.84 & 0.84 & 6.09 \\
Adult female sharks & 39 & 195 & 3.28 & 0.89 & 7.21 \\
Juvenile male sharks & 35 & 139 & 3.04 & 0.86 & 6.89 \\
Adult male sharks & 38 & 204 & 3.21 & 0.88 & 6.96 \\
\hline
\end{tabular}

$S$ : total species; $N$ : total individuals; $H^{\prime}$ : Shannon-Wiener index; $J^{\prime}$ : Pielou's index of evenness and $d$ : Margalef's index of richness.

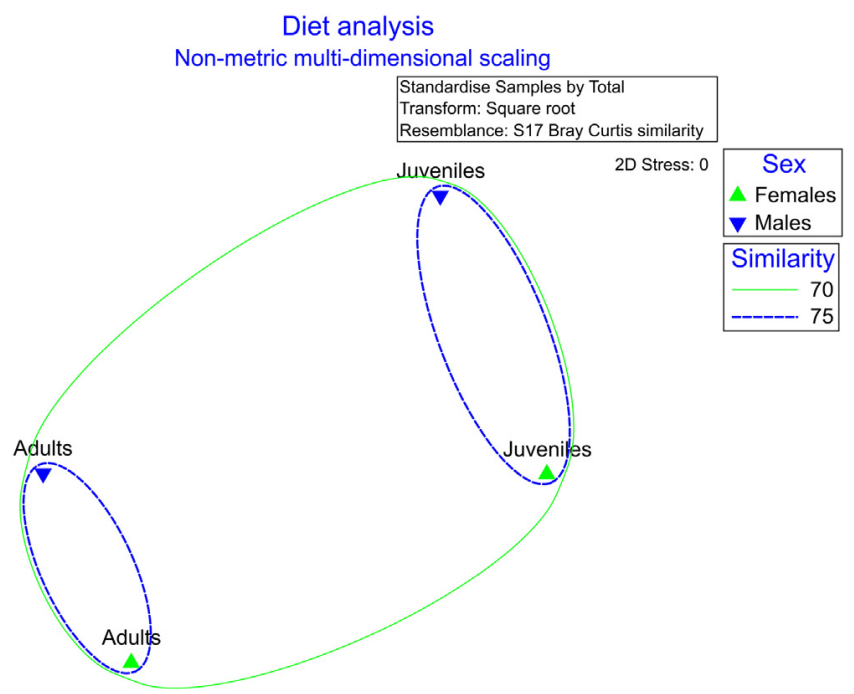

Fig. 6. Non-metric multi-dimensional scaling (MDS) plot with overlaid cluster from dendrogram plot to depict the similarities and dissimilarities among the juveniles and adults of female and male sharks.

food item of the species (Bass et al., 1975; Salini et al., 1990; Ba et al., 2013). The diet composition of $R$. acutus in the Timor and Arafura Sea off northern Australia even had teleosts as high as 93\% in the total diet of shark (Stevens and McLoughlin, 1991).

The diet composition in the present study was found to be quite similar to that of the shark from Cochin waters (India) in the southeastern Arabian Sea, where it has been reported to feed mainly on anchovies, threadfin breams, scads followed by crustaceans like penaeid shrimps and cephalopods such as cuttlefishes and squids (Appukuttan and Nair, 1988). The present results were also found to be in agreement with another study, where unidentified fish (80\%) as well as preys belonging to the families Clupeidae, Leiognathidae, Engraulidae and Penaidae have been reported to constitute the food items of the shark along the Cleveland Bay of Australia (Simpfendorfer and Milward, 1993). Similarly, Jabado et al. (2015) has documented Engraulidae (anchovies), Gerreidae and Lutjanidae as the most commonly occurring fishes in the diet of the shark from Persian Gulf. However, the observation from south-western Bay of Bengal was different, where silver bellies (Gerreidae) have been described as the predominant prey species of the shark followed by cephalopods and crustaceans (Appukuttan and Nair, 1988). Nevertheless, all these findings, despite their partial differences in terms of exact species composition of the prey items from location to location, elucidate one common pattern in the diet preference of the shark where small teleosts are seen as the most preferred prey items followed by crustaceans and cephalopods. The slight differences in prey preference observed in the present study could be due to the spatial variation which has been documented from several earlier studies (Salini et al., 1990, 1992; Stevens and McLoughlin, 1991; Simpfendorfer et al., 2001; Ba et al., 2013). As the abundance and composition of the prey species change with geographic location, a concurrent difference in diet composition for an opportunistic small shark like $R$. acutus could be expected.

The dominant prey species in the stomachs could be used as a proxy for their abundance in the region. The large numbers of prey items and high biodiversity indices for the prey items, in the present study, suggest that $R$. acutus might be an opportunistic feeder in this region. With a broadest continental shelf and largest coastline in India peninsula, the state of Gujarat bears one of the richest and diversified marine ecosystems of Arabian Sea which provides a very conducive feeding ground for predators. This makes the shark an opportunistic feeder though it is little selective too. The occurrence of clupeids, engraulids and carangids in the stomachs of $R$. acutus both from the present as well as earlier studies indicates a sort of preference and selectivity for these prey species (Salini et al., 1990; Stevens and McLoughlin, 1991; Simpfendorfer and Milward, 1993; White et al., 2004; Ba et al., 2013). The presence of both pelagic as well as demersal fishes in the diets suggests that, though the species is a pelagic predator, it performs vertical movements to feed on a wider range of preys like other sharks (White et al., 2004; Sims et al., 2008; Nakamura et al., 2011).

The sexual and ontogenetic differences in feeding behaviour have previously been reported in $R$. acutus as well as other shark species (Ba et al., 2013; Ellis and Musick, 2007). The lower vacuity index of females compared to the males simply implies that the number of sharks with empty stomachs was lower in females. The lower index of relative fullness (IRF) and the mean number of

Table 4

Comparison of feeding behaviour between the sexes and sexual maturity stages of Rhizoprionodon acutus from Gujarat waters.

\begin{tabular}{llllllll}
\hline Sex and maturity stage & $S$ & $N$ & $N$ items & $W$ items & $V I$ & $M P S$ & $I R F$ \\
\hline Female sharks & 363 & 196 & 343 & 4668.95 & 46.01 & 1.75 & $1.95^{\mathrm{a} *}$ \\
Male sharks & 321 & 159 & 312 & 4157.28 & 50.47 & 1.96 & $2.03^{\mathrm{b} *}$ \\
Juvenile sharks & 372 & 156 & 256 & 3502.11 & 58.06 & 1.64 & $2.61^{\mathrm{b} *}$ \\
Adult sharks & 312 & 199 & 399 & 5324.12 & 36.22 & 2.01 & $1.61^{\mathrm{a} *}$ \\
Juvenile female sharks & 204 & 86 & 117 & 1586.76 & 57.84 & 1.36 & $3.48^{\mathrm{c \#}}$ \\
Adult female sharks & 159 & 110 & 195 & 2570.52 & 30.82 & 1.77 & $1.50^{\mathrm{a} \#}$ \\
Juvenile male sharks & 168 & 70 & 139 & 1915.35 & 58.33 & 1.99 & $2.25^{\mathrm{b} \#}$ \\
Adult male sharks & 153 & 89 & 204 & 2753.60 & 41.83 & 2.29 & $1.84^{\text {ab\# }}$ \\
Sharks total & 684 & 355 & 655 & 8826.23 & 48.10 & 1.85 & \\
\hline
\end{tabular}

$\mathrm{S}$ : number of stomachs analysed, $\mathrm{N}$ : number of stomachs containing food, $N$ items: number of prey items, $W$ items: weight of prey items, QI: dietary coefficient (QI), IRI: index of relative importance, VI: vacuity index, MPS: mean number of prey per stomach and IRF: index of relative fullness; *Mann-Whitney U test results, values with different superscript varies significantly $(P<0.05)$; ${ }^{*}$ Kruskal-Wallis test results, values with different superscript varies significantly $(P<0.05)$ 
preys per stomach in the females suggest that compared to males, the female sharks feeds not only less in quantity with respect to its body weight but also lesser number of prey items. Less number of preys for females also indicates their higher selectivity or preference for prey items compared to the males. The variations in feeding behaviour have also been reported between the males and females in several earlier studies (Klimley, 1987; Stillwell and Kohler, 1993; Simpfendorfer et al., 2001; McCord and Campana, 2003). These differences could be related to the sexual segregation resulting from gender-specific preferences in the food searching sites as well as the difference in the stomach size between the males and females (Klimley, 1987; McCord and Campana, 2003; Capape et al., 2006). However, despite a visible difference in the IRI\% of major prey groups, the preference for individual prey items was not found to be significantly different between the females and males.

In the present study, milk shark was also found to have different IRF, vacuity index and mean number of preys per stomach at different maturity stages. The higher vacuity index of the juveniles simply implies that the number of sharks with empty stomachs was higher in the juveniles. The lower index of relative fullness and higher mean number of prey per stomach in the adults suggest that compared to the juveniles, they feed less in quantity with respect to their body weight but choose larger number of preys. This could be due to the larger mouth size and better experienced predation skills of the adult predators considerably reduce handling time for the prey, which results in higher foraging success rate (Juanes et al., 2001). An advantageous foraging skill could have helped the adults to predate on more number of preys. On the other hand, the lower preys number per stomach of juveniles could be due to their lack of experience to predate on wider range of agile prey items which could have impelled them to pursue less number of easy prey items. The differences in the feeding habits among the juveniles, and adults might be size related segregation. It has been reported earlier that many juvenile sharks occupy habitats different from those of the larger sharks to avoid cannibalism (Lowe et al., 1996). These findings agree with previously published studies on feeding habits of several shark species (Stillwell and Kohler, 1982; Cortes and Gruber, 1990; Lowe et al., 1996). This was further corroborated not only by the visible difference in the IRI\% of major prey groups but also from the differential preference for the individual prey items which was significantly different between the juveniles and adults of both the sexes.

In the present study, the lowest IRF was observed in the adult females. On the other hand, the highest IRF was recorded for the juvenile females. This could be due to the fact that the pregnant female sharks lose their agility as well as swift predation skill and become sluggish due to the extra weight in the form of growing embryos inside their bodies. As the maturity occurs, especially for the females, most of the energy demands of the body are diverted for reproduction, such as gonad development and gestation that might trigger shifts in the feeding habits. This often involves a change in habitat utilization, which forces the female sharks from pelagic to more demersal habitat that increases the prey size while decreasing its availability (Alonso et al., 2002).

\section{Conclusions}

The diet composition study of a species gives an indication about the health of the ecosystem. Since, sharks are the top predators they rely on a wide array of teleosts along with shrimps, prawns, crabs and other invertebrates. However, the ever-increasing fishing pressure since the new introductions of trawlers along Gujarat coast is swiping most of the resources resulting in excessive removal of its prey items as by-catch and discards which in turn could influence the feeding habit of the sharks. Usually sharks are migratory in nature and the decreased prey abundance may trigger them to move to other coasts. In the case of $R$. acutus, no previous information about its feeding habits is available from the north-eastern Arabian region and hence it is difficult to conclude that its population might have suffered due to the scarcity of prey items. However, the present study will definitely provide necessary baseline information about the feeding ecology of the shark and thus will be helpful in understanding the future trophodynamics of the species under the influence of overfishing and climate change.

\section{Acknowledgements}

The authors would like to express sincere gratitude to Dr. Gopal Krishna, Director, CIFE, Mumbai; Dr. A. Gopalakrishnan, Director, CMFRI, Cochin and Mr. Mohammed Koya K., Scientist-in-charge, Regional centre of CMFRI, Veraval for providing facilities and encouragement to carry out the above study. The authors are also thankful to Indian council of agricultural research, New Delhi Grant in Aid Code 201 for providing the financial support for the logistics involved in the research work.

\section{References}

Alonso, M.K., Crespo, E.A., Garcia, N.A., Pedraza, S.N., Mariotti, P.A., Mora, N.J., 2002. Fishery and ontogenetic driven changes in the diet of the spiny dogfish, Squalus acanthias, in Patagonian waters, Argentina. Environ. Biol. Fish. 63, 193-202.

Appukuttan, K.K., Nair, K.P., 1988. Shark resources of india, with notes on biology of a few species. In: Mohan, J.M. (Ed.), Proceedings of first Indian fisheries forum. Asian Fisheries Society, Indian Branch, Mangalore, pp. 173-183.

Ba, A., Diop, M.S., Diatta, Y., Justine, D., Ba, C.T., 2013. Diet of the milk shark Rhizoprionodon acutus (Chondrichthyes: Carcharhinidae), from the Senegalese coast. J. Appl. Ichthyol. 29, 789-795.

Barry, K.P., Condrey, R.E., Driggers, W.B., Jones, C.M., 2008. Feeding ecology and growth of neonate and juvenile blacktip sharks Carcharhinus limbatus in the Timbalier-Terrebone Bay complex, LA, U. S.A. J. Fish Biol. 73, 650-662.

Bass, A.J., D'Aubrey, J.D., Kistnasamy, N., 1975. Sharks of the east coast of southern Africa. V. The families Hexanchidae, Chlamydoselachidae, Heterodontidae, Pristiophoridae and Squatinidae. South African Association for Marine Biological Research, Oceanographic Research Institute Investigational Report No. 43.

Bellemans, M., Sagna, A., Fischer, W., Scialabba, N., 1988. Fisheries resource guide of Senegal and Gambia (marine and brackish water species). In: FAO Species Identification Sheets for the Purpose of Fishing. FAO, Rome, Italy, p. 227.

Bonfil, R., 1994. Overview of world elasmobranch fisheries. In: FAO Fisheries Technical Paper, 341. FAO, Rome, Italy, p. 119.

Cadenat, J., Blache, J., 1981. Sharks from the Mediterranean and Atlantic (especially from the western coast of Africa). Faune Trop. ORSTOM 21, 1-330.

Camhi, M., Fowler, S.L., Musick, J.A., Brautigam, A., Fordham, S.V., 1998. Sharks and their relatives-ecology and conservation. In: Occasional Paper of the IUCN Species Survival Commission No. 20. IUCN/SSC Shark Specialist Group, IUCN, Gland, Switzerland and Cambridge, UK, p. 39

Capape, C., Diatta, Y., Diop, M., Guelorget, O., Vergne, Y., Quignard, J., 2006. Reproduction in the milk shark, Rhizoprionodon acutus (Ruppell, 1837) (Chondrichthyes: Carcharhinidae), from the coast of Senegal (eastern tropical Atlantic). Acta Adriatica 47 (2), 111-126.

Capape, C., Diop, M., N'Dao, M., 1994. Observations on the reproductive biology of seventeen species of economical interest captured in the marine area of DakarOuakam (Senegal, Eastern Tropical Atlantic). Bull. Inst. Fondam Africa Noire A 47, 87-102.

Compagno, L.J.V., 1984. Sharks of the World. An annotated and illustrated catalogue of shark species to date. Part II (Carcharhiniformes). In: FAO Fisheries Synopsis. FAO, Rome, Italy, p. 655

Cortes, E., 1997. A critical review of methods of studying fish feeding based on analysis of stomach contents: application to elasmobranch fishes. Can. J. Fish. Aquat. Sci. 54, 726-738.

Cortes, E., 1999. Standardized diet compositions and trophic levels of sharks. ICES J. Mar. Sci. 56, 707-717.

Cortes, E., Gruber, S.H., 1990. Diet, feeding habits, and estimates of daily ration of young lemon sharks, Negaprion brevirostris (Poey). Copeia 20, 4-218.

Ellis, J.K., Musick. J.A., 2007. Ontogenetic changes in the diet of the sandbar shark Carcharhinus plumbeus, in lower Chesapeake Bay and Virginia (USA) coastal waters. Environ. Biol. Fish. 80, 51-67.

Fischer, W., Bianchi, G., Scott, W.B., 1981. FAO species identification sheets for fishery purposes. Eastern Central Atlantic; fishing area 34, 47 (in part). Vols. 1-7, Canada Funds-in-Trust. Ottawa, Department of Fisheries and Oceans Canada, by 
arrangement with the Food and Agriculture Organization of the United Nations, Italy, Rome.

Gelsleichter, J., Musick, J.A., Nichols, S., 1999. Food habits of the smooth dogfish, Mustelus canis, dusky shark, Carcharhinus obscurus, Atlantic sharpnose shark, Rhizoprionodon terraenovae, and the sand tiger, Carcharias taurus, from the northwest Atlantic Ocean. Environ. Biol. Fish. 54, 205-217.

Heithaus, M.R., Frid, A., Wirsing, A.J., Worm, B., 2008. Predicting ecological consequences of marine top predator declines. Trends Ecol. Evol. 23 (4), 202-210.

Hyslop, E.J., 1980. Stomach contents analysis: a review of methods and their application. J. Fish Biol. 17, 415-429.

Jabado, R.W., Ghias, S.M., Hamza, W., Henderson, A.C., Al Mesafri, A.A., 2015. Diet of two commercially important shark species in the United Arab Emirates: Milk shark, Rhizoprionodon acutus ((Ruppell, 1837), and slit-eye shark, Loxodon macrorhinus (Muller and Henle, 1839). J. Appl. Ichthyol. 31 (5), 870-875.

Juanes, F., Buckel, J.A., Scharf, F.S., 2001. Predatory behaviour and selectivity of a primary piscivore: comparison of fish and non-fish prey. Mar. Ecol. Prog. Ser. 217, 157-165.

Kizhakudan, S.J., Zacharia, P.U., Thomas, S., Vivekanandan, E., Menon, M., 2015. Guidance on national plan of action for shark in India. In: CMFRI Marine Fisheries Policy Series no. 2, CMFRI, Kochi, Kerala, p. 104.

Klimley, A.P., 1987. The determinates of sexual segregation in the scalloped hammerhead sharks, Sphyrna lewini. Environ. Biol. Fish. 18, 27-40.

Lowe, C.G., Wetherbee, B.M., Crow, G.L., Tester, A.L., 1996. Ontogenetic dietary shifts and feeding behavior of the tiger shark, Galeocerdo cuvier, in Hawaiian waters. Environ. Biol. Fish. 47, 203-211.

McCord, M.E., Campana, S.E., 2003. A quantitative assessment of the diet of the blue shark (Prionace glauca) off Nova Scotia, Canada. J. Northw. Atl. Fish. Sci. 32, $57-$ 63.

Nakamura, I., Watanabe, Y.Y., Papastamatiou, Y.P., Sato, K., Meyer, C.G., 2011. Yoyo vertical movements suggest a foraging strategy for tiger sharks Galeocerdo cuvier. Mar. Ecol. Prog. Ser. 424, 237-246.

Rosecchi, E., Nouaze, Y., 1987. Comparison of five dietary indices used in the analysis of stomach contents. Rev. Travaux Inst. des Peches Maritimes 49, 111-123.

Salgado, J.P., Cabral, H.N., Costa, M.J., 2004. Feeding ecology of the gobies Pomatoschistus minutus (Pallas, 1770) and Pomatoschistus microps (Kroyer, 1838) in the upper Tagus estuary, Portugal. Sci. Mar. 68, 425-434.

Salini, J.P., Blaber, S.J.M., Brewer, D.T., 1990. Diets of piscivorous fishes in a tropical Australian estuary, with special reference to predation on penaeid prawns. Mar. Biol. 105, 363-374.
Salini, J.P., Blaber, S.J.M., Brewer, D.T., 1992. Diets of sharks from estuaries and adjacent waters of the North-eastern Gulf of Carpentaria, Australia. Mar. Freshwater Res. 43, 87-96.

Sen, S., Chakraborty, S.K., Vivekanandan, E., Zacharia, P.U., Kizhakudan, S.J., Jaiswar A.K., Dash, G., Jayshree, G., 2017. Population dynamics and stock assessment of milk shark, Rhizoprionodon acutus (Ruppell, 1837) along Gujarat coast of India. Indian J. Geo-Mar. Sci. 46, 936-946.

Seret, B., Opic, P., 1981. Marine fish of tropical West Africa. In: Initiations and documentations techniques No. 49. p. 455.

Simpfendorfer, C.A., 2003. Rhizoprionodon acutus. In: IUCN 2011. IUCN Red List of Threatened Species. Version 2011.1. Available at: http://www.iucnredlist.org. (Accessed on 24 August 2011).

Simpfendorfer, C.A., Goodreid, A.B., McAuley, R.B., 2001. Size, sex and geographic variation in the diet of the tiger shark, Galeocerdo cuvier, from Western Australian waters. Environ. Biol. Fish. 61, 37-46.

Simpfendorfer, C.A., Milward, N.E., 1993. Utilization of a tropical bay as a nursery area by sharks of the families Carcharhinidae and Sphyrnidae. Environ. Biol. Fish. 37, 337-345.

Sims, D.W., Southall, E.J., Humphries, N.E., Hays, G.C., Bradshaw, C.J.A., Pitchford, J.W., James, A., Ahmed, M.Z., Brierley, A.S., Hindell, M.A., Morritt, D., Musyl, M.K., Righton, D., Shepard, E.L.C., Wearmouth, V.J., Wilson, R.P., Witt, M.J., Metcalfe, J.D., 2008. Scaling laws of marine predator search behaviour. Nature 451, 1098 1102.

Stevens, J.D., Bonfil, R., Dulvy, N.K., Walker, P.A., 2000. The effects of fishing on sharks, rays, and chimaeras (Chrondrichthyans), and the implications for marine ecosystems. ICES J. Mar. Sci. 57, 476-494.

Stevens, J.D., McLoughlin, K.J., 1991. Distribution, size and sex composition, reproductive biology and diet of sharks from Northern Australia. Mar. Freshwater Res. 42, 151-199.

Stillwell, C.E., Kohler, N.E., 1982. Food, feeding habits, and estimates of daily ration of the shortfin mako (Isurus oxyrinchus) in the Northwest Atlantic. Can. J. Fish. Aquat. Sci. 39, 407-414.

Stillwell, C.E., Kohler, N.E., 1993. Food habits of the sandbar shark Carcharhinus plumbeus off the U.S. northeast coast, with estimates of daily ration. Fish. Bull. 91, 138-150.

Vivekanandan, V., 2001. An Ill-Thought Ban. Samudra 30, pp. 3-9. Available: www. icsf.net/jsp/publication/samudra/pdf/english/issue_30/art01.pdf.

White, W.T., Platell, M.E., Potter, C., 2004. Comparisons between the diets of four abundant species of elasmobranchs in a subtropical embayment: implications for resource partitioning. Mar. Biol. 144, 439-448. 